ISSN 0258-7122

Bangladesh J. Agril. Res. 40(1): 137-151, March 2015

\title{
FIELD PERFORMANCE AND FRUIT QUALITY OF STRAWBERRY GENOTYPES UNDER SUBTROPICAL CLIMATE
}

\author{
M. MOSHIUR RAHMAN ${ }^{1}$, M. M. RAHMAN ${ }^{2}$, M. M. HOSSAIN ${ }^{2}$ \\ M. A. KHALEQUE Mian ${ }^{3}$ AND Q. A. KHALiQ ${ }^{4}$
}

\begin{abstract}
Thirteen strawberry genotypes collected from different sources were evaluated at the Fruit Research Field of Pomology Division, HRC, BARI, Gazipur, Bangladesh during the winter season of 2009-2010 and 2010-2011 for yield, yield contributing characters and nutrient components of fruit. Among the 13 genotypes studied, the plants of FA 005 produced the maximum number of fruits (43.50 plant $^{-1}$ ) followed by FA 006 and FA 007 (37.50 plant $^{-1}$ ), while FA 009 and FA 013 produced the minimum number of fruits $\left(9.00\right.$ plant $\left.^{-1}\right)$. The heaviest fruits were produced by FA 006 (18.73 g) followed by FA 007 (17.40 g) and FA 005 (16.96 g) which were statistically similar, while the lightest fruit was found in FA $014(5.11 \mathrm{~g})$. The fruit yield plant ${ }^{-1}$ of different genotypes varied from 52.00 to $737.70 \mathrm{~g}$ and plants of FA 005 produced the maximum yield followed by FA 006 (702.30 g plant $\left.^{-1}\right)$ and these were significantly higher than those of others. The minimum yield plant ${ }^{-1}$ was recorded in FA 013 and FA 014. The TSS content was highest in FA 007 (8.50\%) followed by FA 017 (8.17 $\%)$, whereas the lowest was in FA $009(6.33 \%)$. The TSS to acid ration was maximum in FA 006 (11.32) followed by FA 017 (11.24), FA 007 (10.80) and FA 005 (10.62), while the lowest was in FA 011 (6.95). The sugar to acid ratio significantly ranging from 3.60 to 5.98, and it was maximum in FA 006 (5.98). Plants of FA 005 contained the maximum amount of ascorbic acid $(77.33 \mathrm{mg}$ $\left.100 \mathrm{~g}^{-1}\right)$ followed by FA $006\left(76.00 \mathrm{mg} 100 \mathrm{~g}^{-1}\right)$, while the minimum in FA 010

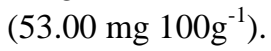

Keyword: Strawberry, field performance, yield, fruit quality

\section{Introduction}

Strawberries (Fragaria $x$ ananassa Duch) is a highly appreciated fruit for its excellent flavour, wonderful taste, attractive colour, high nutrient profile and cosmic medicinal value. Strawberry is now grown successfully in Bangladesh. It was demonstrated that genotype is the main source of variation and single most important factor that influenced the growth, yield and quality of fruit. Today's strawberry

\footnotetext{
${ }^{1}$ Senior Scientific Officer, Horticulture Research Centre (HRC), Bangladesh Agricultural Research Institute (BARI), Gazipur, ${ }^{2}$ Professor, Department of Horticulture, Bangabandhu Sheikh Mujibur Rahman Agricultural University (BSMRAU), Gazipur, ${ }^{3}$ Professor, Department of Plant Breeding, BSMRAU, Gazipur, ${ }^{4}$ Professor, Department of Agronomy, BSMRAU, Gazipur, Bangladesh.
} 
comprises about 500 commercial cultivars grown worldwide (Galletta and Maas, 1990; Hancock, 1999). Hence, a germplasm pool with good variability for the desirable characters is the basic requirement of any crop improvement program (Singhania et al., 2006). On the other hand, crop improvement is primarily dependent on extensive evaluation of available genotypes. Therefore, the choice of a cultivar is of paramount importance for successful strawberry cultivation (Asrey and Singh, 2004). As a new crop it is necessary to evaluate the yield, yield contributing and quality characters of fruits under Bangladesh condition. Yield and yield contributing characters is the ultimate goal of any crop production and the fruit quality and nutrient components is the basic requirement of a crop. Hence, studies about these important traits are necessary for successful cultivation of this crop in a new area like Bangladesh.

Bangladesh Agricultural Research Institute (BARI) has released one variety of strawberry namely BARI Strawberry-1, which is not enough for increasing demand of strawberry cultivation. So it is necessary to develop more variety of this promising crop with higher yield, fruit quality and nutrient profile. There are very little studies done on the performance regarding yield, yield contributing, fruit quality and nutrient components of strawberry in Bangladesh. However, a good number of investigations were done in USA, India, UK, Thailand, Turkey and elsewhere in the world. Therefore, the present study was undertaken to evaluate the collected strawberry genotypes for fruit, yield, yield contributing characters, quality parameters and nutritional components of fruits and to select superior ones.

\section{Materials and Method}

The present study was carried out at the Fruit Research Farm of Horticulture Research Centre, Bangladesh Agricultural Research Institute (Latitude $23^{\circ} 59^{\prime} \mathrm{N}$, Longitude $90^{\circ} 24^{\prime} \mathrm{E}$, Altitude $14.33 \mathrm{~m}$ ), Gazipur, Bangladesh during winter season of 2009-2010 and 2010-2011. This region falls in sub-tropical zone having hot summers (May-August) and mild winter (December-February). Cumulative rainfall of about $108 \mathrm{~mm}$ during cultivation period with average $79.4 \%$ relative humidity. The mean maximum and minimum temperature during cropping period were 25.89 and $17.05^{\circ} \mathrm{C}$, respectively. Soil of the experimental farm was clay loam, having pH 6.2 (slightly acidic), which was low in organic carbon $(0.95 \%)$, very low in available phosphorus $(9 \mathrm{ppm})$ and low in potash $(0.17 \mathrm{meq} / 100 \mathrm{~g}$ soil $)$.

Healthy and disease free propagules of 'thirteen strawberry genotypes collected from local and exotic source were considered as treatment and planted in the experiment field the only released strawberry variety namely BARI Strawberry-1 used as check. 
The experiment was laid out in randomized complete block (RCB) design with three replications. The unit plot size was $100 \times 280 \mathrm{~cm}$ and the plants were spaced $50 \times 40 \mathrm{~cm}$ on open beds. Beds were raised $30 \mathrm{~cm}$ above main field with $50 \mathrm{~cm}$ drain in-between 2 beds. Each plot contains double row accommodating 14 plants. Daughter plants of strawberry genotypes were planted on 15 October, 2009 and 2010. Data were collected from inner plants from each row to avoid border effect. In each unit plot ten inner plants were selected for recording data.

Runners were removed at every 3 to 4 days intervals in order to make the crown capable to initiate flowers. Straw mulch was applied around the plants as a normal practice in order to conserve soil moisture, decreasing weed and to provide healthy condition for the fruits. Weeds were removed at 15 days interval up to final harvest to keep the crop weed free. Irrigation was given at 7 days interval and whenever necessary to keep the soil moisture available in the field for better plant growth. All other necessary cultural practices and plant protection measures were followed uniformly for all the plots and treatments during the entire period of experimentation. Fruits were usually harvested by hand picking during early in the day when environment was cool, at an interval of 3 to 4 days and handled very carefully. The fruits were harvested at commercial maturity when $>80 \%$ of the fruit surface showing red colour. Immediately after harvest, strawberries were sorted to eliminate damaged fruit, and selected for uniform size and colour for collecting data.

The following qualitative characters of fruit viz. shape, uniformity, colour, firmness and flavour were recorded by close observation according to the descriptors for strawberry (IBPGR, 1986). On the other hand, number of fruits plant $^{-1}$, fruit weight $(\mathrm{g})$, fruit length $(\mathrm{cm})$, fruit diameter $(\mathrm{cm})$, yield plant ${ }^{-1}(\mathrm{~g})$, days to harvest, harvest duration, deform fruits (\%) and number of achenes fruit ${ }^{-1}$ were recorded for quantitative fruit characters. Following chemical and nutrient components were recorded viz. reducing sugar, non-reducing sugar, total sugar, total soluble solid (TSS), $\mathrm{pH}$, titratable acidity, TSS to acid ratio, sugar to acid ratio and ascorbic acid contents of fruits.

Two year's data of different quantitative parameters were pooled and analyzed, following RCB design using MSTAT-C program. The mean comparison was done following the Duncan's Multiple Range Test (DMRT).

\section{Results and Discussion}

\section{Qualitative characters of fruits}

Qualitative characters of different strawberry genotypes was studied and shown in Table 1. Fruit shape of different strawberry genotypes was classified into 6 shapes. 
Plants of FA 001, BARI Strawberry-1, FA 008 and FA 011 produced conical shaped fruits. While fruits of FA 007 and FA 017 were long conical shaped. On the other hand, FA 006 and FA 016 produced wedged shaped fruits. Fruits of FA 009 and FA 013 was oblate shaped, and that of FA 010 and FA 014 was round shaped and FA 005 was cordate shaped. This findings are similar to that of Jamieson (2003) and Rahman and Ahmad (2009). Uniformity of fruits of different strawberry genotypes was studied and categorized into high, intermediate and low grade. Genotypes of FA 005, FA 006, FA 007, FA 016 and FA 017 produced highly uniform fruits. While fruits of BARI Strawberry-1, FA 008, FA 011 and FA 013 were intermediate in fruit uniformity. Rest of the genotypes produced fruits having low uniformity. Colour of fruits of different strawberry genotypes was studied and classified into light, intermediate, dark and very dark category. Fruits of FA 009, FA 010, FA 013 and FA 014 had light colour. While those of FA 001, FA 008 and FA 011 were intermediate in colour, BARI Strawberry-1, FA 006 and FA 016 had dark, FA 005, FA 007 and FA 017 had very dark coloured fruis.

Table 1. Qualitative characters of fruits in strawberry genotypes.

\begin{tabular}{|c|c|c|c|c|c|}
\hline Genotypes & $\begin{array}{l}\text { Shape of } \\
\text { fruits }\end{array}$ & $\begin{array}{l}\text { Uniformity of } \\
\text { fruits }\end{array}$ & $\begin{array}{l}\text { Colour of } \\
\text { fruits }\end{array}$ & $\begin{array}{c}\text { Fruit } \\
\text { firmness }\end{array}$ & $\begin{array}{l}\text { Flavour of } \\
\text { fruits }\end{array}$ \\
\hline FA 001 & Conical & Low & Intermediate & Very soft & Slight \\
\hline FA 005 & Cordate & High & Very Dark & Intermediate & Excellent \\
\hline FA 006 & Wedged & High & Dark & Firm & Excellent \\
\hline FA 007 & Long Conic & High & Very dark & Very Firm & Excellent \\
\hline FA 008 & Conical & Intermediate & Intermediate & Very soft & Excellent \\
\hline FA 009 & Oblate & Low & Light & Soft & Poor \\
\hline FA 010 & Round & Low & Light & Soft & Good \\
\hline FA 011 & Conical & Intermediate & Intermediate & Very Soft & Good \\
\hline FA 013 & Oblate & Intermediate & Light & Very Soft & Poor \\
\hline FA 014 & Round & Low & Light & Intermediate & Slight \\
\hline FA 016 & Wedged & High & Dark & Firm & Excellent \\
\hline FA 017 & Long Conic & High & Very dark & Very Firm & Excellent \\
\hline $\begin{array}{l}\text { BARI } \\
\text { Strawberry-1 }\end{array}$ & Conical & Intermediate & Dark & Soft & Good \\
\hline
\end{tabular}

Fruit firmness of different strawberry genotypes was classified into 5 categories viz. very soft, soft intermediate, firm and very firm. Among the genotypes, FA 001, FA 008, FA 011 and FA 013 produced very soft fruits. Whereas fruits of BARI Strawberry-1, FA 009 and FA 010 were soft textured. On the other hand, fruits of FA 005 and FA 014 were intermediate textured. Fruits of FA 006 and FA 016 were 
firm and those of FA 007 and FA 017 were very firm in texture. Zhang et al. (2010) found that fruits of 'Shu Xiang' were very firm in texture. Fruit flavour was classified into 4 group viz. absent, poor, slight, good and excellent. Among the genotypes FA 009 and FA 013 produced fruits with poor in flavour, FA 001 and FA 014 were of slight in flavour. While fruits of BARI Strawberry-1, FA 010 and FA 011 were good in flavour, and FA 005, FA 006, FA 007, FA 008, FA 016 and FA 017 produced fruits with excellent flavour. Rahman and Ahmad (2009) stated that fruit flavour of different strawberry lines distinguishably differed and varied from poor to excellent. Similar fruit flavour was observed in the present investigation.

\section{Yield and yield contributing characters}

Average number of fruits plant $^{-1}$ exhibited wide range of variation among the genotypes (Table. 2). The highest number of fruits (43.50) was harvested from FA 005 distantly followed by BARI Strawberry-1 (39.00), FA 017 (38.51), FA 006 (37.50), FA 016 (37.50), FA 008 (37.50) and FA 007 (36.00). The lowest number of fruits (9.00) was produced by the genotype FA 009 and FA 013. Asrey and Singh (2004) found a significant variation in fruits plant $^{-1}$ among the cultivars ranging from 25.33 to 40.66 . This result is in conformity with the present finding. Lutchoomun and Cangy (1997) found that strawberry cv. 'Marquise' produced the highest number of fruits plant ${ }^{-1}$ (69) followed by 'Mara des bois' (62), while single plant of cv. 'Selva' produced only 31 fruits which was higher than present observation. The variation in fruits plant $^{-1}$ is due to inherent capability of the genotypes, and also influences of growing environment. The genotype significantly influenced the fruit weight (Table.2). The heaviest fruits were produced by FA 006 $(18.73 \mathrm{~g})$ closely followed by FA 007 (17.40 g) and FA 005 (16.96 g), while the lightest fruit was found in FA $014(5.11 \mathrm{~g})$. Fruit weight recorded in the present experiment was strongly similar to the findings of Crespo (2010), who stated that $\mathrm{cv}$. Asia produced heaviest fruit $(26.4 \mathrm{~g})$ and cv. Antea produced the lightest fruits (14.8 g). Present findings are also confirmed with the previous reports of Cordenunsi et al. (2002) and Asrey and Singh (2004). They found that single fruit weight of strawberry varied significantly among the studied genotypes. In respect of length and diameter all the genotypes varied significantly probably due to the inherent characters of genotype (Table 2). The longest fruits were produced by FA 007 $(5.10 \mathrm{~cm})$ followed by FA $005(4.50 \mathrm{~cm})$, FA $017(4.50 \mathrm{~cm})$ and FA $006(4.40 \mathrm{~cm})$ and the shortest fruits were produced by FA-014 $(1.30 \mathrm{~cm})$. The thickest fruit was found in FA $006(4.20 \mathrm{~cm})$ followed by FA $005(4.10 \mathrm{~cm})$ and FA $007(3.80 \mathrm{~cm})$. The thinnest fruit was produced by FA $013(1.30 \mathrm{~cm})$. This result fully agrees with the previous findings of Asrey and Singh (2004) and Cordenunsi et al. (2002). 
Asrey and Singh (2004) observed that the size of strawberry fruits among the genotypes varied significantly and fruit length of different strawberry cultivar ranged from 3.49 to $4.21 \mathrm{~cm}$ and fruit width ranged from 2.91 to $3.40 \mathrm{~cm}$, respectively.

Table 2. Yield and yield contributing characters in strawberry genotypes

\begin{tabular}{|c|c|c|c|c|}
\hline Genotypes & $\begin{array}{l}\text { Fruits plant }{ }^{-1} \\
\text { (No.) }\end{array}$ & $\begin{array}{l}\text { Fruit weight } \\
\text { (g) }\end{array}$ & $\begin{array}{l}\text { Fruit length } \\
\quad(\mathrm{cm})\end{array}$ & $\begin{array}{l}\text { Fruit diameter } \\
\qquad(\mathrm{cm})\end{array}$ \\
\hline FA 001 & $25.50 \mathrm{c}$ & 9.95 ef & $3.40 \mathrm{~d}$ & $2.50 \mathrm{de}$ \\
\hline FA 005 & $43.50 \mathrm{a}$ & $16.96 \mathrm{ab}$ & $4.50 \mathrm{ab}$ & $4.10 \mathrm{ab}$ \\
\hline FA 006 & $37.50 \mathrm{~b}$ & $18.73 \mathrm{a}$ & $4.40 \mathrm{ab}$ & $4.20 \mathrm{a}$ \\
\hline FA 007 & $36.00 \mathrm{~b}$ & $17.40 \mathrm{ab}$ & $5.10 \mathrm{a}$ & $3.80 \mathrm{a}-\mathrm{c}$ \\
\hline FA 008 & $37.50 \mathrm{~b}$ & $12.07 \mathrm{de}$ & $3.90 \mathrm{~b}-\mathrm{d}$ & $3.30 \mathrm{bc}$ \\
\hline FA 009 & $9.00 \mathrm{f}$ & $9.04 \mathrm{fg}$ & $2.20 \mathrm{e}$ & $2.20 \mathrm{e}$ \\
\hline FA 010 & $16.50 \mathrm{e}$ & $7.35 \mathrm{gh}$ & $2.00 \mathrm{e}$ & $2.20 \mathrm{e}$ \\
\hline FA 011 & $21.00 \mathrm{~d}$ & $7.14 \mathrm{gh}$ & $2.10 \mathrm{e}$ & $2.10 \mathrm{e}$ \\
\hline FA 013 & $9.00 \mathrm{f}$ & $5.78 \mathrm{~h}$ & $1.50 \mathrm{ef}$ & $1.30 \mathrm{f}$ \\
\hline FA 014 & $13.50 \mathrm{ef}$ & $5.11 \mathrm{~h}$ & $1.30 \mathrm{f}$ & $1.70 \mathrm{ef}$ \\
\hline FA 016 & $37.50 \mathrm{~b}$ & $15.33 \mathrm{bc}$ & $4.20 \mathrm{bc}$ & $3.77 \mathrm{a}-\mathrm{c}$ \\
\hline FA 017 & $38.51 \mathrm{~b}$ & $14.47 \mathrm{c}$ & $4.50 \mathrm{ab}$ & $3.63 \mathrm{a}-\mathrm{c}$ \\
\hline BARI Strawberry-1 & $39.00 \mathrm{~b}$ & $13.35 \mathrm{~cd}$ & $3.63 \mathrm{~cd}$ & $3.20 \mathrm{~cd}$ \\
\hline $\mathrm{CV}(\%)$ & 6.78 & 8.61 & 8.92 & 11.28 \\
\hline
\end{tabular}

Figures having the same letter(s) in a column do not differ significantly by DMRT at $1 \%$ level of significant.

The analysis of variance indicated a high degree of variation among the genotypes in yield plant ${ }^{-1}$ (Fig. 1). The highest yield plant $^{-1}$ was recorded from the genotype FA $005(737.70 \mathrm{~g})$ followed by FA $006(702.30 \mathrm{~g})$ and was significantly higher than others. The lowest yield plant ${ }^{-1}$ was recorded from FA $013(52.00 \mathrm{~g})$. The variation in yield plant $^{-1}$ was might be due to the inherent character of the genotypes. This was in agreement with the findings of following investigations. From different experiments Lutchoomun and Cangy (1997) and Crespo (2010) stated that fruit yield plant ${ }^{-1}$ in strawberry varied significantly among the cultivars studied ranging from 179.00 to $312.40 \mathrm{~g}$ and 386.00 to $624.00 \mathrm{~g} \mathrm{plant}^{-1}$, respectively. 


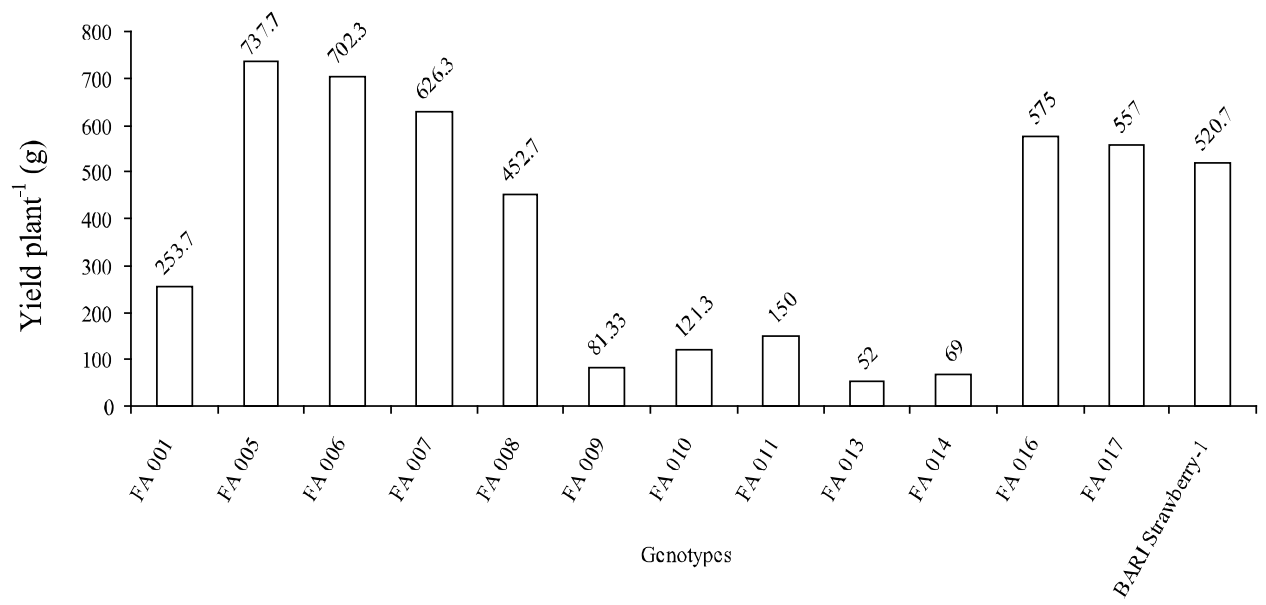

Fig. 1. Yield plant $^{-1}$ in different strawberry genotypes.

The analysis of variance indicates a high degree of variation among the genotypes in days to harvest (Table 3). The genotypes, FA 011 required the minimum days (25.37) for attaining full maturity to harvest from flowering preceded by FA 013 (27.33 days), FA 010 (27.33 days), FA 009 (27.67 days) and FA 014 (28.67). While genotypes FA 007 required maximum days (35.67) from flowering to harvesting. This is in line with the findings of Klein and Perry (1982), who stated that strawberry usually, takes more or less 30 days to achieve full size and maturity of fruits. Anon. (2010) noted that fruits of strawberry matured rapidly, ripening occurs in 20 to 50 days after pollination. Harvest duration is an important character and it indicates a period during which a genotype is able to produce fruits. The longest harvest duration was observed in the genotype FA 007 (94 days) followed by FA 006 (93.67 days) and FA 005 (92.00 days). While, FA 014 had the shortest harvest duration (70.67 days) (Table 3). As a consequence the source-sink relation varies during the harvest and may affect the fruits composition. A significant variation among the strawberry cultivars in harvest duration under conventional system was observed by Macit et al. (2007), which is similar with present result.

The analysis of variance indicates a high degree of variation among the genotypes in yield plant ${ }^{-1}$ (Table 3). Among the genotypes, FA 001 produced minimum (10.33 $\%)$ deformed fruits preceded by FA 008 and FA 010 (12.33\%), while FA 014 produced maximum $(26.00 \%)$ deformed fruits. There was a remarkable variation among the genotypes of strawberry in number of achenes fruit ${ }^{-1}$ (Table 3 ) and it ranged from 186.70 to 473.30 . The highest number of achenes fruit ${ }^{-1}$ was observed in FA 007 (473.30) closely followed by FA 006 (471.70), FA 017 (460.70), FA 016 (460.30) and FA 005 (441.70). The lowest number of achenes fruit ${ }^{-1}$ was found in 
FA 013 (186.70). Hansen (1989) stated that strawberry fruits differed in fruit weight and achenes number fruit $^{-1}$.

Table 3. Days to harvest, harvest duration, percentage of deform fruits and number of achenes fruit ${ }^{-1}$ in strawberry genotypes.

\begin{tabular}{l|c|c|c|c}
\hline \multicolumn{1}{c|}{ Genotypes } & $\begin{array}{c}\text { Days to } \\
\text { harvesting }\end{array}$ & $\begin{array}{c}\text { Harvest } \\
\text { duration }\end{array}$ & $\begin{array}{c}\text { Percentage of } \\
\text { deform fruits }\end{array}$ & Achenes fruit $^{-1}$ \\
\hline FA 001 & $29.67 \mathrm{de}$ & $88.67 \mathrm{ab}$ & $10.33 \mathrm{e}$ & $272.30 \mathrm{bc}$ \\
FA 005 & $33.33 \mathrm{a}-\mathrm{c}$ & $92.00 \mathrm{a}$ & $21.00 \mathrm{bc}$ & $441.70 \mathrm{a}$ \\
FA 006 & $34.33 \mathrm{ab}$ & $93.67 \mathrm{a}$ & $23.33 \mathrm{ab}$ & $471.70 \mathrm{a}$ \\
FA 007 & $35.67 \mathrm{a}$ & $94.00 \mathrm{a}$ & $24.33 \mathrm{ab}$ & $473.30 \mathrm{a}$ \\
FA 008 & $29.67 \mathrm{de}$ & $90.00 \mathrm{ab}$ & $12.33 \mathrm{e}$ & $315.00 \mathrm{~b}$ \\
FA 009 & $27.67 \mathrm{ef}$ & $89.00 \mathrm{ab}$ & $16.33 \mathrm{~d}$ & $276.70 \mathrm{bc}$ \\
FA 010 & $27.33 \mathrm{ef}$ & $90.00 \mathrm{ab}$ & $12.33 \mathrm{e}$ & $221.70 \mathrm{~cd}$ \\
FA 011 & $25.67 \mathrm{f}$ & $85.00 \mathrm{~b}$ & $19.33 \mathrm{~cd}$ & $210.30 \mathrm{~cd}$ \\
FA 013 & $27.33 \mathrm{ef}$ & $76.00 \mathrm{c}$ & $24.33 \mathrm{ab}$ & $186.70 \mathrm{~d}$ \\
FA 014 & $28.67 \mathrm{ef}$ & $70.67 \mathrm{c}$ & $26.00 \mathrm{a}$ & $191.70 \mathrm{~d}$ \\
FA 016 & $30.33 \mathrm{c}-\mathrm{e}$ & $90.67 \mathrm{ab}$ & $23.00 \mathrm{ab}$ & $460.30 \mathrm{a}$ \\
FA 017 & $32.00 \mathrm{~b}-\mathrm{d}$ & $89.00 \mathrm{ab}$ & $23.67 \mathrm{ab}$ & $460.70 \mathrm{a}$ \\
BARI Strawberry-1 & $29.33 \mathrm{de}$ & $88.67 \mathrm{ab}$ & $16.00 \mathrm{~d}$ & $334.70 \mathrm{~b}$ \\
\hline \multicolumn{1}{c}{ CV (\%) } & 6.34 & 3.05 & 7.51 & 8.42 \\
\hline
\end{tabular}

Figures having the same letter(s) in a column do not differ significantly by DMRT at $1 \%$ level of significant.

\section{Relationship between number of achenes fruit ${ }^{-1}$ and fruit weight}

A positive linear relationship was observed between number of achenes fruit ${ }^{-1}$ and fruit weight $(\mathrm{g})$. The equation was $\mathrm{y}=0.0393 \mathrm{x}-1.3015$ with highly significant value of coefficient of determination $\left(\mathrm{R}^{2}=0.9396^{* *}\right)$ shown in Fig. 2. This regression line coupled with a significant regression coefficient indicated that fruit weight would be increased with a significant manner with the increase in number of achenes fruit ${ }^{-1}$. So, there is a clear indication that the genotypes having more achenes produced larger fruits. This result corroborates the statement of Darnell (2003) who stated that number of achenes fruit ${ }^{-1}$ positively increased the size and weight of fruit. Annon. (2010) stated that achenes number positively correlated with fruit size and differed significantly among the cultivars, which agreed with the present investigation. Fertile achenes produce auxins that trigger the growth of receptacles during fruit ripening (Nitsch, 1950; Kronenberg, 1959). When achenes 
are unfertilized, the development of the area on the fruit around the achenes is inhibited, resulting in malformation of the whole fruit (Ledesma et al., 2008).

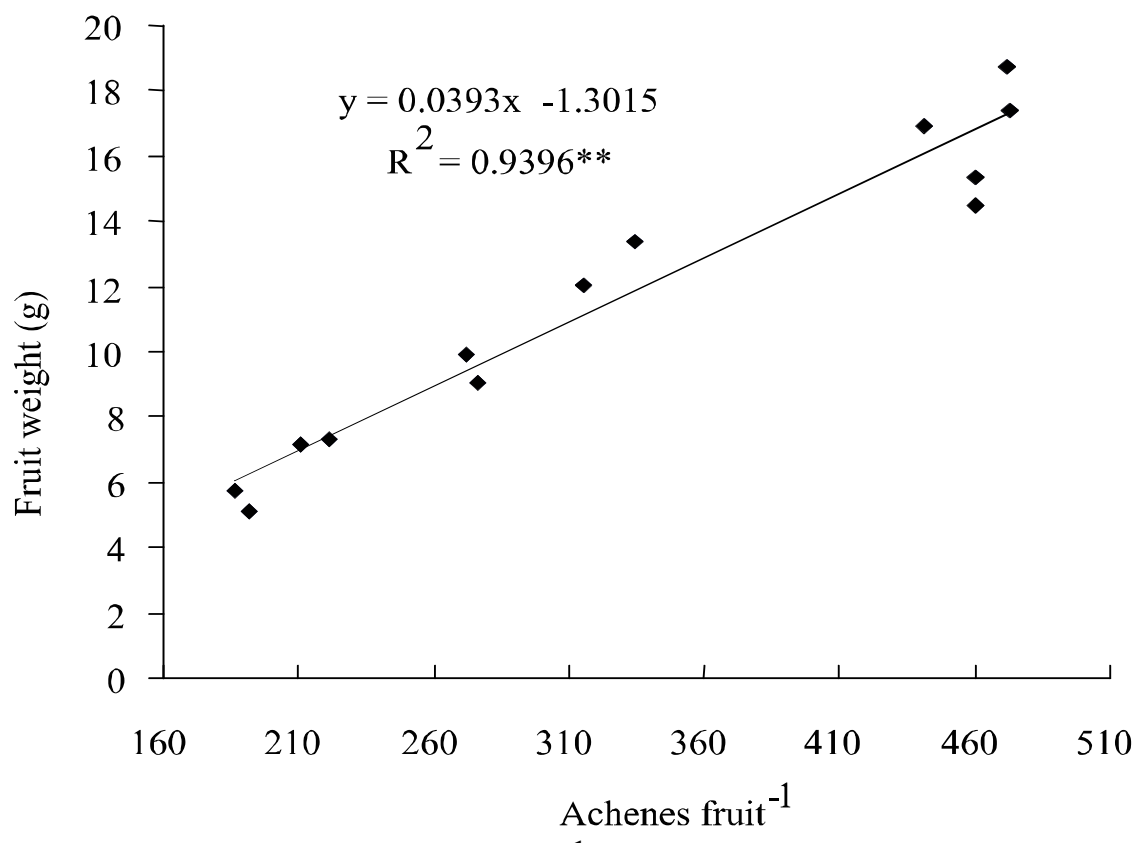

Fig. 2. Relationship between achenes fruit $^{-1}$ and single fruit weight in strawberry.

\section{Chemical and nutrient components}

Highly significant variation was observed in reducing sugar content in fruits of different genotypes (Table 4). The highest quantity of reducing sugar was obtained from FA 006 (2.98 \%) closely followed by FA 005 (2.95 \%), FA 007 (2.94 \%), FA 001 (2.91\%), FA 017 (2.91\%), BARI Strawberry-1 (2.89\%). Result of the present investigation is in accord with those of Asrey and Singh (2004), who revealed a significant variation in reducing sugar content of strawberry. Kader (1991) found a large genotypic variation in reducing sugar content which ranged from 3.7 to 5.2 $\%$. This result is higher than that recorded in the present studies probably due to genotypic and environmental variations.

The quantity of non-reducing sugar of strawberry fruit ranging from 1.10 and 1.39 $\%$ were statistically non significant.

The component, which affects the taste of the fruit, is the sugar content. The result exhibited highly significant difference in the content of total sugar among the genotypes which ranged from $4.28 \%$ to $3.43 \%$ (Table 4 ). The highest quantity of total sugar was obtained from FA 005 closely followed by FA 006 (4.23\%), FA 
$007(4.20 \%)$, FA 016 (4.13 \%), FA 001 (4.10 \%), FA 017 (4.10 \%) and BARI Strawberry-1 (4.02\%), and the lowest total sugar content was obtained in FA 009 $(3.43 \%)$. Total sugar content of strawberry fruits is a heritable trait, and is highly influenced by variability of genotypes. Kader (1991) reported that there is a large genotypic variation in total sugar content of strawberries ranging from 4.10 to 6.60 $\%$. Crespo (2010) stated that total sugar content of strawberry fruits varied among the cultivars and ranged from $40.9 \mathrm{mg} \mathrm{g}^{-1}$ (cv. Matis) to $51.8 \mathrm{mg} \mathrm{g}^{-1}$ (cv. Asia) which supported the result of present investigation.

Total soluble solids (TSS) of fruits of strawberry genotypes varied significantly and ranging from 8.50 to $6.33 \%$ (Table 4). Among the genotypes, FA 007 contained the highest amount of TSS (8.50\%) closely followed by FA 017 (8.17 $\%)$, FA $017(8.17 \%)$, FA 006 (8.00 \%), FA 005 (7.83 \%) and FA 016 (7.67\%). The lowest TSS was exhibited by FA $009(6.33 \%)$. The variation in TSS among the genotypes might be due to the variation of genotypes. Capocasa et al. (2008) found that TSS of strawberry fruits varied significantly and rangedfrom $5.8 \%$ to $9.7 \%$ among the cultivars which is in consonance with the present findings. According to Kader (1991) the TSS content of strawberry fruits harvested at commercial ripening stage ranged from 5 to $12 \%$, depending on cultivar and preharvest factors. This is within the range of the present observation. Resende et al. (2008) recorded the TSS content of different strawberry cultivars ranging from 7.20 to $8.10 \%$, which is similar with the present findings. Asrey and Singh (2004) revealed found a strong cultivar variation in TSS which ranged from 4.90 to 7.50 $\%$ among the cultivars, while Shaw (1988) reported that this variation was mostly affected by environmental factors.

The $\mathrm{pH}$ value of strawberry fruit were statistically non significant and ranged from 3.71 to 3.36. The highest $\mathrm{pH}$ value was obtained from in FA 001 while, the lowest in FA 006, and FA 017 (Table 4). Kafkas et al. (2007) found that the pH ranging from 3.33-3.43 in the ripe stage of the strawberries but did not change significantly, which is strongly in concur with the present findings.

Titratable acidity (TA) varied significantly among the genotypes (Table 5.). The highest titratable acidity was found in FA $011(0.960 \%)$ followed by FA 008 $(0.923 \%)$, FA $013(0.920 \%)$ and FA $001(0.883 \%)$ which were statistically different from others (Table 4). The lowest was found in FA $006(0.707 \%)$. The titratable acidity and the organic acid content are genetically determined and varied significantly among the genotypes, while less influenced by environment (Shaw, 1988). The result about titratable acidity of present studies agrees with those of 
Asrey and Singh (2004), and Resende et al. (2008). They reported that the titratable acidity of strawberry fruits varied significantly and ranged from 0.80 to $0.91 \%$ and 0.60 to $0.88 \%$, respectively among the studied cultivars. Macit et al. (2007) found TA of strawberry genotypes varied from 0.34 to $0.41 \%$, which was lower than present findings and this might be due to differences either in cultivars or in the growing environments.

Table 4. Chemical component and nutrient content of fruits in strawberry.

\begin{tabular}{|c|c|c|c|c|c|c|}
\hline Genotypes & $\begin{array}{c}\text { Reducing } \\
\text { sugar } \\
(\%)\end{array}$ & $\begin{array}{c}\text { Non reducing } \\
\text { sugar } \\
(\%)\end{array}$ & $\begin{array}{c}\text { Total sugar } \\
(\%)\end{array}$ & $\begin{array}{l}\text { TSS } \\
(\%)\end{array}$ & $\mathrm{pH}$ & $\begin{array}{c}\text { Titratable } \\
\text { acidity } \\
(\%)\end{array}$ \\
\hline FA 001 & $2.91 \mathrm{a}$ & 1.19 & $4.10 \mathrm{a}-\mathrm{c}$ & $6.83 \mathrm{de}$ & 3.71 & $0.883 \mathrm{ab}$ \\
\hline FA 005 & $2.95 \mathrm{a}$ & 1.13 & $4.28 \mathrm{a}$ & $7.83 \mathrm{a}-\mathrm{c}$ & 3.63 & $0.737 \mathrm{de}$ \\
\hline FA 006 & $2.98 \mathrm{a}$ & 1.34 & $4.23 \mathrm{a}$ & $8.00 \mathrm{ab}$ & 3.44 & $0.707 \mathrm{e}$ \\
\hline FA 007 & $2.94 \mathrm{a}$ & 1.25 & $4.20 \mathrm{a}$ & $8.50 \mathrm{a}$ & 3.36 & $0.787 \mathrm{c}-\mathrm{e}$ \\
\hline FA 008 & $2.80 \mathrm{ab}$ & 1.26 & $4.08 \mathrm{a}-\mathrm{c}$ & $7.17 \mathrm{~b}-\mathrm{e}$ & 3.37 & $0.923 \mathrm{a}$ \\
\hline FA 009 & $2.33 \mathrm{bc}$ & 1.29 & $3.43 \mathrm{~d}$ & $6.33 \mathrm{e}$ & 3.42 & $0.833 \mathrm{bc}$ \\
\hline FA 010 & $2.32 \mathrm{bc}$ & 1.10 & $3.54 \mathrm{~cd}$ & $6.50 \mathrm{e}$ & 3.62 & $0.777 \mathrm{c}-\mathrm{e}$ \\
\hline FA 011 & $2.22 \mathrm{c}$ & 1.22 & $3.46 \mathrm{~d}$ & $6.67 \mathrm{de}$ & 3.37 & $0.960 \mathrm{a}$ \\
\hline FA 013 & $2.21 \mathrm{c}$ & 1.24 & $3.60 \mathrm{~b}-\mathrm{d}$ & $6.83 \mathrm{c}-\mathrm{e}$ & 3.68 & $0.920 \mathrm{a}$ \\
\hline FA 014 & $2.30 \mathrm{bc}$ & 1.39 & $3.44 \mathrm{~d}$ & $6.67 \mathrm{de}$ & 3.41 & $0.820 \mathrm{bc}$ \\
\hline FA 016 & $2.89 \mathrm{a}$ & 1.14 & $4.13 \mathrm{ab}$ & $7.67 \mathrm{a}-\mathrm{d}$ & 3.38 & $0.780 \mathrm{c}-\mathrm{e}$ \\
\hline FA 017 & $2.91 \mathrm{a}$ & 1.24 & $4.10 \mathrm{a}-\mathrm{c}$ & $8.17 \mathrm{a}$ & 3.37 & $0.727 \mathrm{de}$ \\
\hline $\begin{array}{l}\text { BARI } \\
\text { Strawberry-1 }\end{array}$ & $2.89 \mathrm{a}$ & 1.19 & $4.02 \mathrm{a}-\mathrm{c}$ & $7.00 \mathrm{c}-\mathrm{e}$ & 3.36 & $0.790 \mathrm{~cd}$ \\
\hline $\mathrm{CV}(\%)$ & 7.80 & 5.55 & 5.81 & 5.49 & 7.35 & 2.99 \\
\hline
\end{tabular}

Figures having the same letter(s) in a column do not differ significantly by DMRT at $1 \%$ level of significant

Ascorbic acid content of genotypes varied significantly (Fig. 3), and it was found that ascorbic acid content $100 \mathrm{~g}^{-1}$ of pulp was the highest in FA 005 $(77.33 \mathrm{mg})$ followed by FA $006(76.00 \mathrm{mg})$, while the lowest was found in FA $010(53.00 \mathrm{mg})$. Olsson et al. (2004) stated that the ascorbic acid content depends on the species and cultivation conditions, which was corroborated with

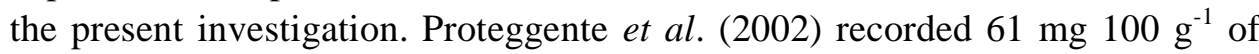
ascorbic acid from fresh strawberry, which is within the range of the present observation. This variation in ascorbic acid content might be due to differences in cultivar and climatic condition. According to Lee and Kader (2000), cultivar type can be defined as an important factor affecting ascorbic content of strawberry. 


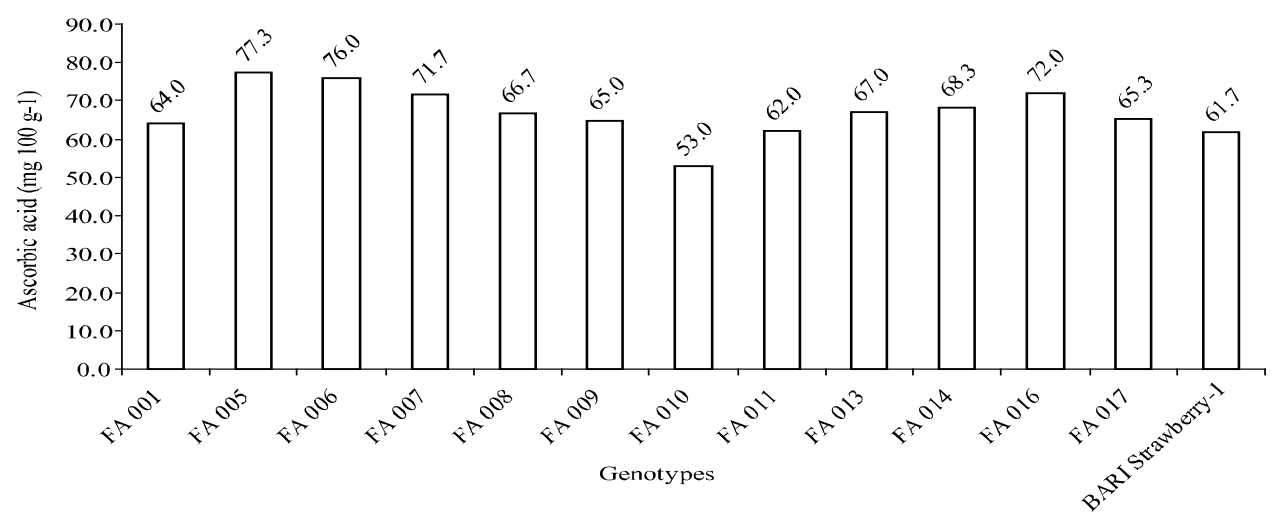

Fig. 3. Ascorbic acid content in fruits of different strawberry genotypes.

The ratio of total soluble solids to acid and sugar to acid is most important for evaluating the taste and determining the maturity of strawberry. According to Kader (1991) high sugar and relatively high acid are required for good flavour. High acid and low sugars produced a tart strawberry, and low acid and high sugar result in a bland taste, while the low sugars and acids, results a tasteless strawberry. The TSS to acid and sugar to acid ratio of fruits of different strawberry genotypes were evaluated and found to be significant (Fig. 4), due to highly significant value of TSS, total sugar and titratable acidity (Table 4). The TSS to acid ratio was found to be highest in FA 006 (11.3) followed by FA 017 (11.2), FA 007 (10.8) and FA 005 (10.6), while the lowest in FA 011 (6.9). The sugar to acid ratio of different genotypes also varied significantly and ranged from 3.6 to 6.0 and followed more or less similar trend of TSS to acid ratio. Among the genotypes, FA 006 exhibited the highest sugar to acid ratio (6.0) followed by FA 005 (5.8) and FA 017 (5.6), while it was lowest in FA 011 (3.6). In an earlier publication, Kafkas et al. (2007) reported that the TSS to acid ratio and the sugar to acid ratio in strawberry varied significantly.

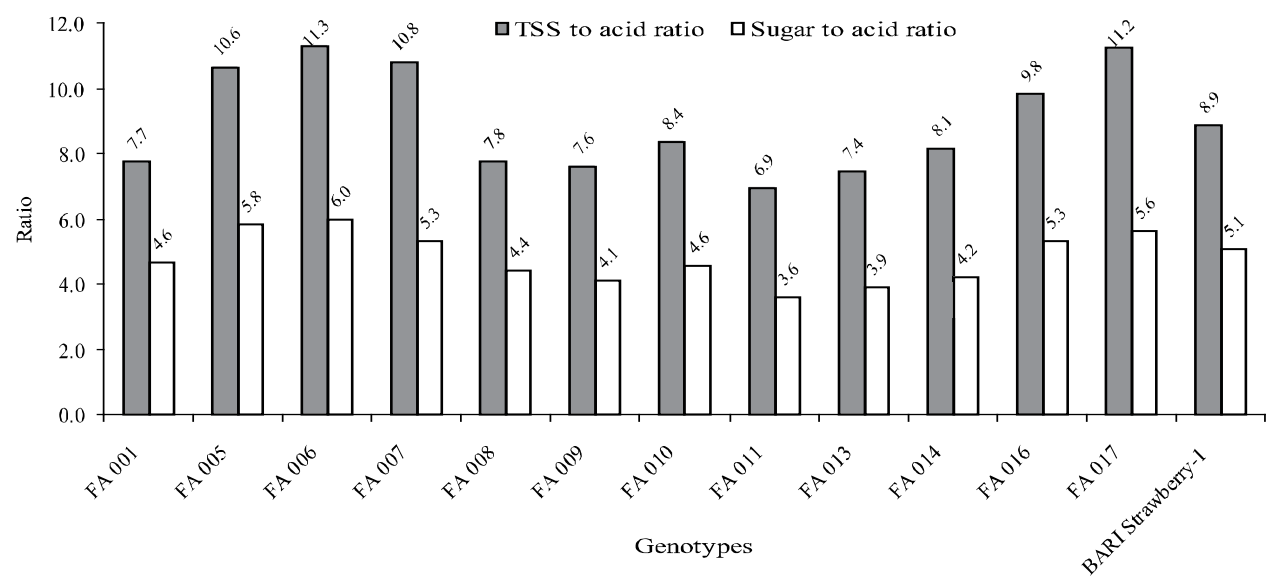

Fig. 4. TSS to acid and sugar to acid ratio in fruits of different strawberry genotypes 


\section{Conclusion}

The genotypes of strawberries showed remarkable variation in nutrient as well as chemical components of fruit. On the basis of physico-morphological characters, it was concluded that genotype FA 006 and FA 007 were identical with FA 016 and FA 017, respectively. Considering total soluble solids (TSS), sugars, ascorbic acid, TSS to acid and sugar to acid ratio of fruits, the genotypes FA 005, FA 006 and FA 007 were superior to others and found to be promising under Bangladesh condition.

\section{References}

Anonymous. 2010. Fruits and fruit juices: 2010. National Nutrient for Standard References, Release, 23. pp. 785-787. US Department of Agriculture, Agriculture Research Service. USDA.

Asrey, R., R. K. Jain and R. Singh. 2004. Effect of pre-harvest chemical treatments on shelf life of Chandler strawberry. Indian J. Agric. Sci. 74: 485-487.

Asrey, R. and R. Singh. 2004. Evaluation of strawberry varieties under semi-arid irrigated region in Punjab. Indian J. Hort. 61(2): 122-124.

Capocasa, F., J. Scalzo, B. Mezzetti and M. Battino. 2008. Combining quality and antioxidant attributes in the strawberry: The role of genotype. Food Chem. 111: 872878.

Cordenunsi, B. R., J. R. O. Nascimento, M. I. Genovese and F. M. Lajolo. 2002. Influence of cultivation quality parameters and chemical composition of strawberry fruits grown in Brazil. J Agric. Food Chem. 50: 2581-2586.

Crespo, P. 2010. Variability of Health and Taste Promoting Compounds in Strawberry (Fragaria $x$ ananassa) Fruits. Ph. D. Thesis. Swiss Federal Institute of Technology, E T H, Zurich, Switzerland. Pp. 10-86.

Darnell, R. L. 2003. Strawberry growth and development. In: The Strawberry, A book for growers, Others. N. F. Childers (ed). Dr. Norman F. Childers Publications, Gainesville, Florida, USA. Pp. 3-11.

Galletta, G. J. and J. L. Maas. 1990. Strawberry genetics. HortScience 25(8): 871- 879. In: The influence of cultivar on sensory profiles of fresh and processed strawberry fruits grown in Croatia. Flavour Fragr. J. 22: 512-520.

Hancock, J. F. 1999. Strawberries. CAB International, Wallingford, Oxford, UK. Pp. 213-237.

Hansen, P. 1989. Source-sink relations in fruits. IV. Fruit number and fruit growth in strawberries. Acta Hortic. 265: 377-381.

IBPGR. 1986. Strawberry Descriptor (Fragaria L). International Board for Plant Genetic Resources. CEC Secretariat, Brussels, Rome. 
Jamieson, A. R. 2003. Strawberry cultivation for perennial production system. In: The Strawberry, A book for growers, Others. N. F. Childers (ed). Dr. Norman F. Childers Publications, Gainesville, Florida, USA. Pp. 167-170.

Kader, A. A. 1991. Quality and its maintenance in relation to the postharvest physiology of strawberry. In: The Strawberry into the $21^{\text {st }}$ Century. J. J. Luby and A. Dale (eds.). Timber Press, Portland, Ore. Pp. 145-152.

Kafkas, E., M. Kosar, S. Paydas, S. Kafkas and K. H. C. Baser. 2007. Quality characteristics of strawberry genotypes at different maturation stages. Food Chem. 100(3): 1229- 1236.

Klein, B. P. and A. K. Perry. 1982. Ascorbic acid and vitamin-A activity in selected vegetables from different geographical areas of the United States. J. Food Sci. 47: 941-945.

Kronenberg, H. G. 1959. Poor fruit setting in strawberries. I. Causes of poor fruit setting in strawberries in general. Euphytica 8: 47-57.

Ledesma, N. A., M. Nakata and N. Sugiyama. 2008. Effect of high temperature stress on the reproductive growth of strawberry cvs. 'Nyoho' and 'Toyonoka'. Sci. Hort. 116: 186-193.

Lee, K. S. and A. A. Kader. 2000. Preharvest and postharvest factors influencing vitaminC content of horticultural crops. Postharvest Biol. Technol. 20: 207-220.

Lutchoomun, S. and C. L. Cangy.1997. Comparison of production systems and varietal evaluation of strawberry. Agricultural Research and Extension Unit. Food and Agricultural Research Council, AMAS. Réduit, Mauritius. Pp. 175-180

Macit, I., A. Koc, S. Guler and I. Deligoz. 2007. Yield, quality and nutritional status of organically and conventionally grown strawberry cultivar. Asian J. plant Sci. 6(7): 1131-1136.

Nitsch, J. P. 1950. Growth and morphogenesis of the strawberry as related to auxin. Am. J. Bot. 37: 211-215.

Olsson, M. E., J. Ekvall, K. E. Gustavsson, J. Nilsson, D. Pillai, I. Sjöholm, U. Svensson, B. Akesson and M. G. Nyman. 2004. Antioxidants, low molecular weight carbohydrates, and total antioxidant capacity in strawberries (Fragaria x ananassa): effects of cultivar, ripening, and storage. J. Agric. Food Chem. 52: 2490-2498.

Proteggente, A. R., A. S. Pannala, G. Paganga, L. Van-Buren, E. Wagner, S. Wiseman, F. van De Put, C. Dacombe and C. A. Rice-Evans. 2002. The antioxidant activity of regularly consumed fruit and vegetables reflects their phenolic and vitamin $\mathrm{C}$ composition. Free Radical Res. 36: 217-233.

Rahman, M. M. and M. R. Ahmad. 2009. Collection and evaluation of strawberry lines. Research Report on Horticultural Crops 2008-2009. Horticulture Research Centre, BARI, Gazipur. Pp. 245-247. 
Resende, J. T. V., L. K. P. Camargo, E. J. S. Argandoña, A. Marchese and C. K. Camargo. 2008. Sensory analysis and chemical characterization of strawberry fruits. Hortic. Bras., 26: 371-374.

Shaw, D. V. 1988. Genotypic variation and genotypic correlation for sugars and organic acids of strawberries. J. Am. Soc. Hortic. Sci. 113: 770-774.

Singhania, D. L., D. Singh and R. S. Raje. 2006. Coriander. In: Ravindran, P. R. K. N. Babu, K. N. Shiva and J. A. Kallupurackal (eds). Advances in Spices and Achievements of Spices Research in India. Agrobios, Agro House,Chopasani Road, Jodhpur 342002. Pp. 678-695.

Zhang Y. T., G. X. Wang, J. Dong, C. F. Zhong, L. N. Wang and L. L. Chang. 2010. A new strawberry cultivar 'Shu Xiang'. Acta Hortic. 37(9): 1541-1542. 